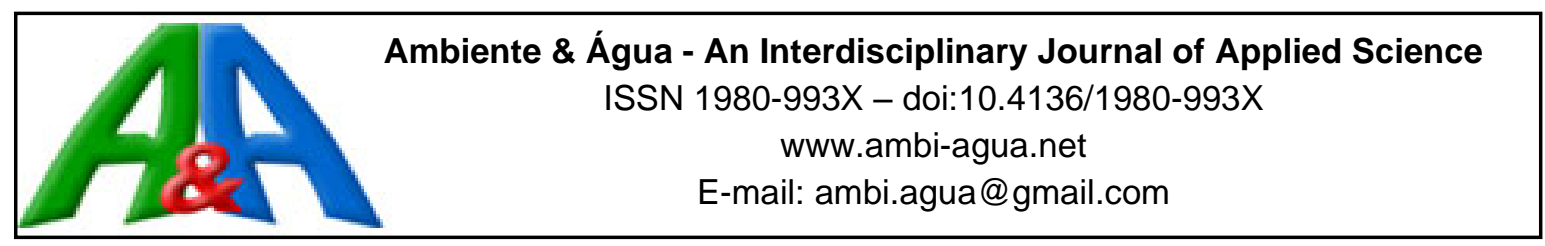

\title{
Evaluation of water loss in transit and surface runoff in a Brazilian semi-arid basin
}

ARTICLES doi:10.4136/ambi-agua.2545

Received: 19 Mar. 2020; Accepted: 18 May 2020

\author{
Cristian Epifanio Toledo*iD; João Carlos Mohn Nogueiraid; \\ Alexandre de Amorim Camargo \\ Departamento de Agronomia. Instituto Acadêmico de Ciências Agrárias e Sustentabilidade. Universidade \\ Estadual de Goiás (UEG), Rua S7, S/N, CEP: 76190-000, Palmeiras de Goiás, GO, Brazil. \\ E-mail: jcmnogueira1@ hotmail.com, camargo_alexandre_work@outlook.com \\ *Corresponding author. E-mail: cristianepifanio@yahoo.com.br
}

\begin{abstract}
The objective of this work was to propose and evaluate a model to estimate transit water losses and surface runoff in a Brazilian semi-arid basin, fundamental components in the hydrological studies of the region, such as in the verification of hydrological connectivity. The study area was the Orós Reservoir Basin, located in the state of Ceará. The modeling of transit water loss and surface runoff were developed based on the work of Araújo and Ribeiro (1996) and Peter et al. (2014). In the proposed model, the parameter of loss in transit (k) was estimated at $0.027 \mathrm{~km}^{-1}$ for a section of the river basin, and when simulated for other stretches it provided good flow results at the end of the stretch, obtaining an NSE of $82 \%$. The value of the runoff coefficient was estimated at $3 \%$ and when evaluating a spatial variation of this coefficient in the basin, the values varied from $2 \%$ to $12 \%$, and the use of specialized runoff coefficient (RC) values promoted a higher NSE in the discharge simulation in the basin. It is concluded that the proposed model to estimate transit water losses and surface runoff demonstrated a high efficiency in the simulation of hydrological processes. The basin of Orós reservoir presented a high variability of the coefficient of surface runoff, justifying the need for a greater spatiality of this coefficient in heterogeneous environments.
\end{abstract}

Keywords: coefficient of runoff, hydrology, modeling.

\section{Avaliação da perda de água em trânsito e do escoamento superficial em uma bacia semiárida brasileira}

\section{RESUMO}

O objetivo deste trabalho foi propor e avaliar um modelo para estimar perdas de água em trânsito e o escoamento superficial em uma bacia semiárida brasileira, componentes fundamentais nos estudos hidrológicos da região, como na verificação da conectividade hidrológica. A área de estudo foi a bacia hidrográfica do reservatório Orós localizada no Estado do Ceará. A modelagem da perda de água em trânsito e do escoamento superficial foi desenvolvida com base nos trabalhos de Araújo e Ribeiro (1996) e Peter et al. (2014). No modelo proposto, o parâmetro de perda em trânsito (k) foi estimado em $0,027 \mathrm{~km}^{-1}$ para um trecho do rio da bacia e quando simulado para outros trechos proporcionou bons resultados da vazão no final do trecho, obtendo um NSE de $82 \%$. O valor do coeficiente de runoff foi 
estimado em $3 \%$ e ao avaliar uma variação espacial desse coeficiente na bacia, os valores variaram de $2 \%$ a $12 \%$, sendo que a utilização os valores do escoamento superficial (RC) especializados promovem um maior NSE na simulação das descargas na bacia. Conclui-se que o modelo proposto para estimar as perdas de água em trânsito e escoamento superficial em uma bacia semiárida brasileira, demonstrou uma alta eficiência na simulação dos processos hidrológicos. A bacia do reservatório de Orós apresentou alta variabilidade do coeficiente de escoamento superficial, justificando a necessidade de maior espacialidade desse coeficiente em ambientes heterogêneos.

Palavras-chave: coeficiente de escoamento, hidrologia, modelagem.

\section{INTRODUCTION}

The Brazilian Semiarid region has been regularly impacted by drought. On average, one severe drought occurs per decade; and sometimes, it occurs continually for many years, which leads to conflicts over water use. Political decisions prioritized the construction of reservoirs, and in Ceará, for example, in only one hydrological basin of the state (Alto Jaguaribe), 4,717 public and private reservoirs were identified in 2011 (Toledo et al., 2014). This policy of dam construction produced a "high-density reservoir network", predominantly composed of smalland medium-sized reservoirs, which consists of a system whose management is complex (Mamede et al., 2018).

In other parts of the world (Gooseff et al., 2017; Ayalew et al., 2017), dense reservoir networks have also been studied using hydrological models, and those studies have emphasized that these networks have been causing interference in water discharge dynamics, by increasing the risk of cascading dam failures and provoking the disruption of hydrological connectivity.

Many elements influence hydrological connectivity, particularly climate, the characteristics of the landscape and anthropic interventions. The climate directly influences the pattern and distribution of flow within a river basin. As a general rule, in the semi-arid and arid regions the conceptual model of hydrological connectivity is more difficult to achieve and occurs less frequently due to limitations like the losses in transit of the runoff (Bracken and Croke, 2007).

Water loss in transit can be defined as the part of the stream flow or reservoir outflow that does not reach a specified downstream point within a specified time. The determination of loss in transit is of key importance when calculating the flow rate required for hydrological connectivity between river sections (Mvandaba et al., 2018; Toledo et al., 2018). An approach to transit water loss along rivers in semiarid regions has used a continuity equation along the river course. This equation is based on the mass balance, taking into account water removal and losses resulting from infiltration and evaporation along a watercourse (Araújo and Ribeiro, 1996).

In the case of loss of flow through downstream infiltration, the long runoff process provides an increase in the probability of infiltration of upstream flow (Medeiros et al., 2010), with this infiltration being influenced by the characteristics of the landscape, such as soil and topography. The soil affects the volume of water that can be infiltrated and defines the rate at which it can occur; and land with higher slope topography allows water to flow more quickly over the surface, which provides less time for water infiltration into the soil (Klein and Klein, 2014).

In this context, this work proposed and evaluated a model to estimate water losses in transit and surface runoff in a Brazilian semi-arid basin, fundamental components in the hydrological studies of the region, such as in the verification of hydrological connectivity. This work also provided an aid tool for decision makers to better understand these processes. 


\section{MATERIALS AND METHODS}

The study area was the Orós Reservoir Basin, which is located in the Alto Jaguaribe Basin. The Orós Basin is located in the southwestern portion of the State of Ceará - Brazil, a region classified as semi-arid, with an annual average temperature of $28^{\circ} \mathrm{C}$, insolation of 2800 hours and precipitation between 500 and $1000 \mathrm{~mm}$, with an average of $751 \mathrm{~mm}$. It has a drainage area of $24211 \mathrm{~km}^{2}$, corresponding to approximately $97 \%$ of the Alto Jaguaribe Basin and $16 \%$ of the state. Toledo et al. (2014), with the support of satellite imagery, identified 4717 public and private reservoirs in 2011 in the Orós Basin, with total water storage capacity of $3646 \mathrm{hm}^{3}$ and $720 \mathrm{~km}^{2}$ of flooded area.

The losses in transit were considered proportional to the flow in the river and estimated according to the modified equation of Araújo and Ribeiro (1996) (Equation 1), which is based on mass balance and considers that the withdrawals and water loss are distributed along a watercourse, making it possible to estimate the flow at the end of a river stretch. Thus, the determination of transit water loss (' $k$ '), using the modified equation of Araújo and Ribeiro (1996), was performed for the study area, providing a calibration and validation for this parameter. I emphasize that evaporation in the course of the river was considered negligible in the original equation as well as in the proposed Equation 1.

$$
Q_{i n p(n)}=Q_{n-1} \cdot e^{-k \cdot \Delta x_{n}}+\left(\Delta x_{n} \cdot \underline{q}+Q_{L O C}\right)
$$

Where, $Q_{\text {inp(n) }}$ is the discharge at the end of a stretch “ $\mathrm{n}$ " $\left(\mathrm{m}^{3} \mathrm{~s}^{-1}\right)$;

$\mathrm{Q}_{(\mathrm{n}-1)}$ is the discharge at the end of the previous stretch (n-1) and thus discharge at the beginning of the current stretch;

" $\mathrm{k}$ " is the transmission loss coefficient;

$\Delta \mathrm{x}_{\mathrm{n}}$ is the length of stretch " $\mathrm{n}$ " $(\mathrm{km})$;

$\underline{q}$ is the distributed or diffuse discharge that enters the rivers $\left(\mathrm{m}^{3} \mathrm{~s}^{-1} \mathrm{~km}^{-1}\right)$;

QLOC is the discharge that enters the river in concentrated mode from an affluent river.

To perform the calibration and validation of parameter ' $\mathrm{k}$ ', a stretch of the Jaguaribe River was chosen, located between in the municipalities of Jucás and Iguatu (Figure 1A). It is 61.4 $\mathrm{km}$ long and is monitored by hydrometric stations upstream known as Sítio Patos, and Iguatu, downstream. Another advantage of choosing this stretch is that the discharges of the river affluent to the stretch, Bastiões and Cariús, are monitored by hydrometric stations (Q $\mathrm{Q}_{\text {LOC }}$ ), all located in the Orós Basin. All the hydrometric stations mentioned are controlled by the Geological Survey of Brazil (Companhia de Serviço Geológico do Brasil), whose information is available in the HidroWeb database, being sampled in a time series from 2000 to 2011.

The calibration of transmission loss parameter ' $\mathrm{k}$ ' was manually performed by trial and error, in which the starting value in use was $0.001 \mathrm{~km}^{-1}$, which was increased by $0.0001 \mathrm{~km}^{-1}$ in each cycle, always seeking to optimize the objective function by means of the index of Nash and Sutcliffe - NSE. In the validation, the discharges simulated with the calibrated ' $k$ ' parameter, for a different period (calibration - 2000 to 2005 and validation - 2006 to 2011) than the one used in the calibration, were compared with the discharges measured at the hydrometric station.

The contribution of distributed flow $(q)$ are surface runoff flows that enter the sub-stretch of the river by small draining courses and/or by direct runoff from the slope to the river. For the distributed flow, as well as the flow of an affluent river without hydrometric monitoring, the 
proposal is to use the Rational Method Equation; however, in the estimation of the distributed flow $(\underline{q})$, the total flow in the section is divided by the length of the river (x), obtaining the specific flow per unit of length.
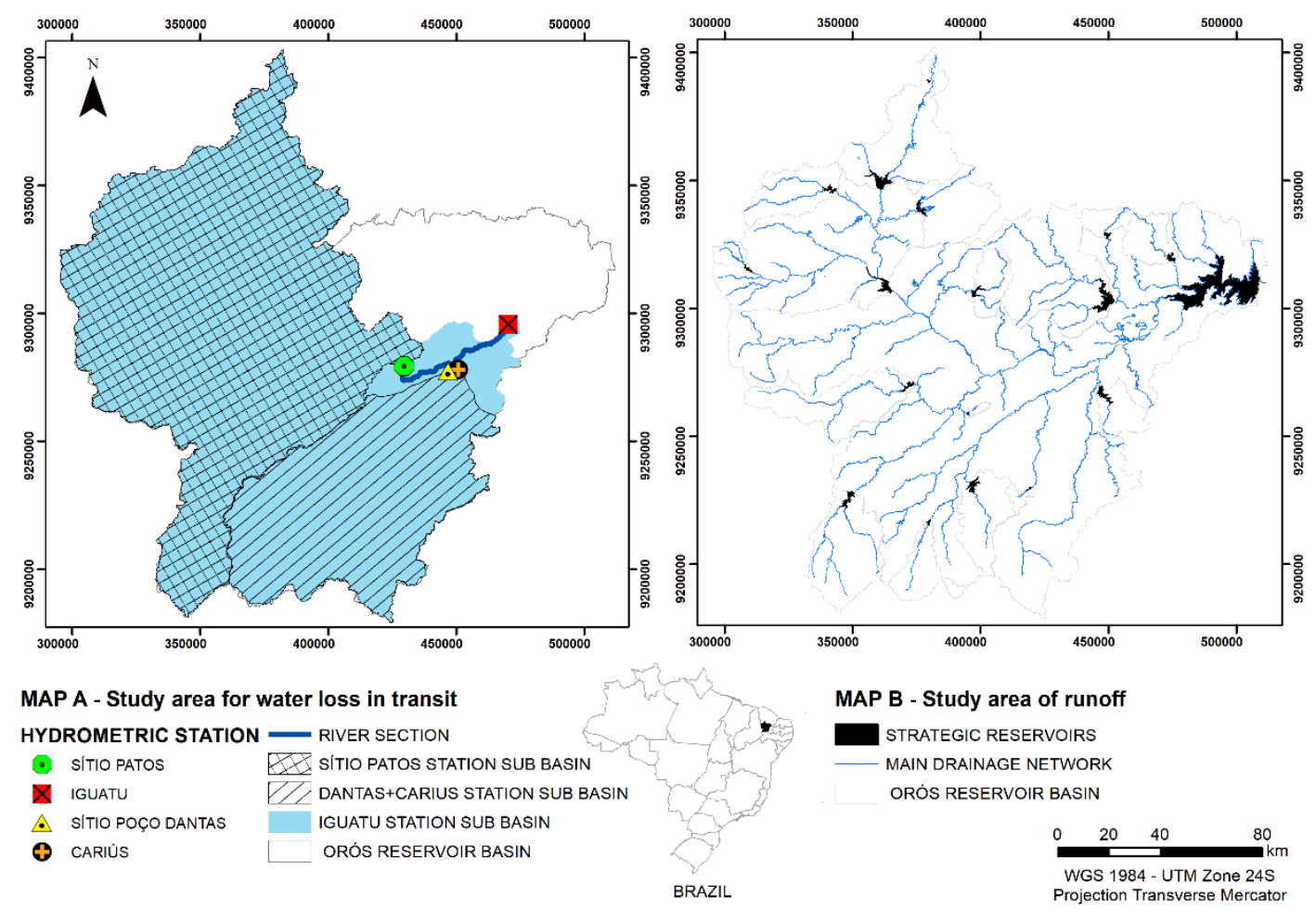

Figure 1. MAPA A - Location of the hydrological stations, their sub-basins, and the section of the Jaguaribe River used to estimate the loss in transit of water; and MAPA B - Location of the 18 strategic reservoirs and their sub-basins used to estimate runoff.

Precipitation was considered equal to the time of 24 hours, the area equal to the size of the basin of direct contribution to the river stretch on both sides, and the runoff coefficient (RC) was estimated varying over time as a function of the antecedent precipitation Equation 2, based on Peter et al. (2014):

$P_{t+\Delta t} \neq 0 \rightarrow R C_{t+1}=R C_{t}+K_{a m p l} P_{t+\Delta t}=0 \rightarrow R C_{t+1}=R C_{t} \cdot K_{\text {red }}$

Where, $\mathrm{RC}_{\mathrm{t}+1}$ is the runoff coefficient in the new time step;

$\mathrm{RC}_{\mathrm{t}}$ is the surface runoff coefficient of the preceding time step;

$\mathrm{P}_{\mathrm{t}+1}$ is the precipitation in the new time step;

$\mathrm{K}_{\mathrm{ampl}}$ is the amplification factor;

$\mathrm{K}_{\text {red }}$ is the reduction factor of the runoff coefficient.

Obtaining the runoff coefficient takes into account that, on each rainy day, soil moisture tends to increase; consequently, the infiltration rate is reduced and surface runoff increases. Similarly, when there is no rain the soil tends to get dry, and thus infiltration increases, thereby reducing surface runoff. In order to simulate the drying and wetting of soil, amplitude and reduction parameters were proposed to correct the runoff coefficient, called $\mathrm{K}_{\mathrm{amp}}$ and Kred, respectively. 
In this study, values of Kamp and Kred were calibration for the whole basin of the Orós Reservoir and for each sub-basin of the 18 reservoirs considered strategic (Figura $1 \mathrm{~B}$ ) for the management of the water resources of the basin and are monitored by the Water Resource Management Company of the State of Ceará (COGERH). The values of Kamp and Kred obtained for the sub-basins, besides providing an analysis of the temporal variability, also allow observation of the spatial variability of the coefficient runoff.

The calibration of parameters $K_{a m p}$ and $K_{\text {red }}$ was performed with the Simplex method for solution of linear problems and the Generalized Reduced Gradient method (GRG) for solution of non-linear problems. Thus, the measured discharges (registered) were compared with the simulated discharges of the study areas, considering the Rational Method Equation and Equation 2. To start the searching process, the initial RC value was 0.04 and the parameters $\mathrm{K}_{\mathrm{amp}}$ and $\mathrm{K}_{\mathrm{red}}$ received the values of 0.60 and 0.92, respectively (Peter et al., 2014). The criteria to stop the calibration corresponded to the maximum value in the function-objective of NSE. In order to prevent physically unreal values, one restriction was enforced: the parameters $K_{a m p}$ and $\mathrm{K}_{\mathrm{red}}$ should be higher than or equal to 0.001 .

In the validation, the discharges simulated using the calibrated parameters $K_{a m p}$ and $K_{\text {red, }}$, were compared to the measured discharges of a different period than the one used in the calibration, and the efficiency coefficient NSE was used for evaluating performance. For comparison purposes, comparisons were also made between measured discharges and simulated discharges by using fixed RC values $0.02 ; 0.03 ; 0.04 ; 0.05 ; 0.06 ; 0.07 ; 0.08$ and 0.09 .

The calibration of parameters $\mathrm{K}_{\mathrm{amp}}$ and $\mathrm{K}_{\mathrm{red}}$ for the whole area of Orós Basin was based on the discharge data of hydrometric station Sítio Patos and precipitation data of pluviometric stations found in the draining area $\left(13670 \mathrm{~km}^{2}\right)$ of the referred hydrometric station. The calibration of the specific values of $K_{a m p}$ and $K_{\text {red }}$ for each sub-basin of the strategic reservoirs of Orós Basin was based on the pluviometric data of the area and the daily affluent flows of the reservoirs. These affluent flows were determined by the water balance in surface reservoirs according to Costa et al. (2012), which included the measured data of volume, outflow of the reservoirs, precipitation and evaporation of the climatological stations situated in the sub-basin area.

\section{RESULTS AND DISCUSSION}

After analysis of the data from the Sítio Patos station for the period of 2000 - 2011, 142 events were identified (Figure 2). The events lasted from 1 to 27 days and the daily discharge in Sítio Patos station (Qo) ranged from 0.34 to $426 \mathrm{~m}^{3} \mathrm{~s}^{-1}$. These events provided daily discharge values in Iguatu station (Qf) from 0 to $920 \mathrm{~m}^{3} \mathrm{~s}^{-1}$ and in Sítio Dantas and Cariús stations, from 0 to $696 \mathrm{~m}^{3} \mathrm{~s}^{-1}$. The indirect control area (Asc) of $948 \mathrm{~km}^{2}$ generated lateral diffuse discharge $(q)$ between 0.004 and $1.66 \mathrm{~m}^{3} \mathrm{~s}^{-1} \mathrm{~km}^{-1}$, which results in a total entry discharge which varies depending on the event from 0 to $102 \mathrm{~m}^{3} \mathrm{~s}^{-1}$. Discharge losses per event varied from 2 to $100 \%$, with an average of $70 \%$. These values are consistent with those found by Costa et al. (2013), that when analyzing the transmission losses in the rivers of the State of Ceará, found loss values between 25 and $100 \%$ of the drained volume.

The analysis of losses of drained volume according to annual rainfall showed that in years of low rainfall, e.g., 2001, transmission losses were $100 \%$ of the discharge that had entered the section. However, in humid years, such as 2008 and 2009, in which time intervals between the events in the rainy period were short ( $<6$ days), the average water losses of the events were $28 \%$ of the discharge that had entered the stretch.

The lower relative loss of drained volume in humid years is attributed to the continuous fluvial discharge. In the first events of fluvial discharge, that is, at the beginning of the rainy season each year, large losses of drained volume occurred, as in other years. This volume is lost 
in recharging the alluvial aquifers that are present along the river channel, as in other years. However, precipitation constancy and, consecutively, the continuous presence of fluvial discharge cause less considerable losses.

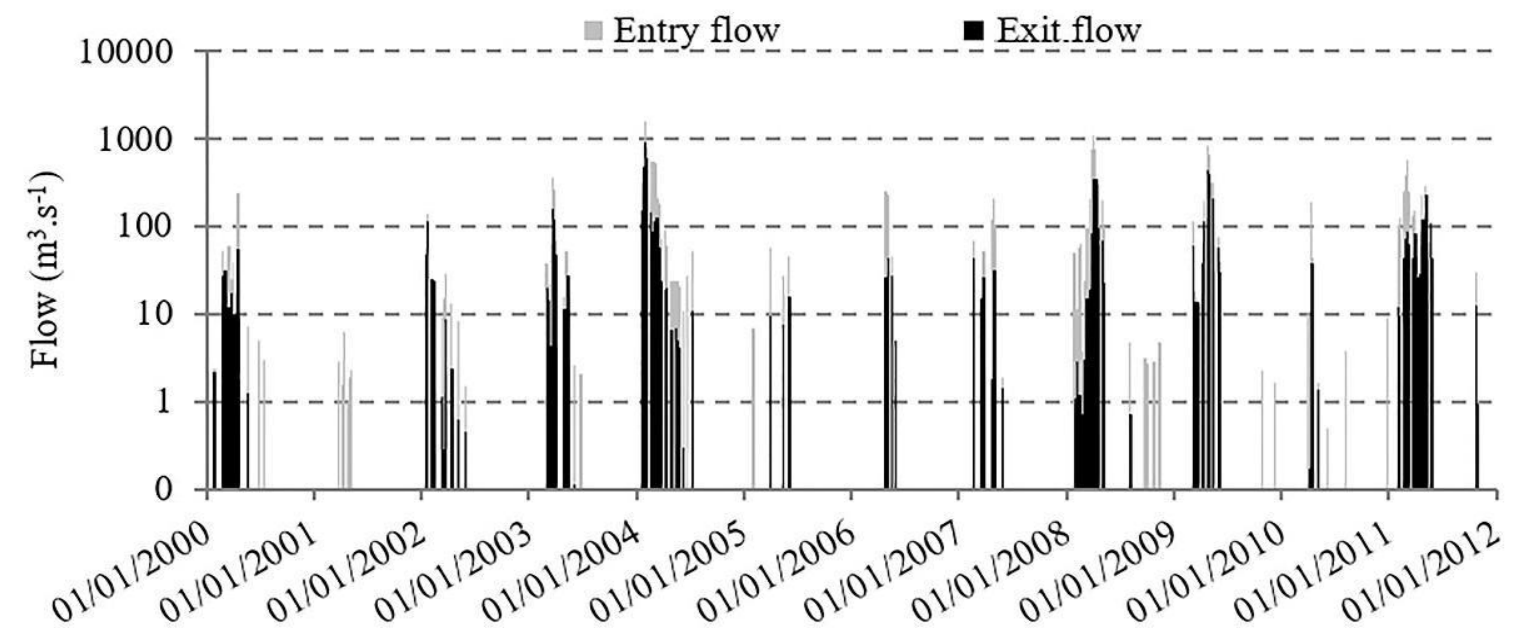

Figure 2. Values of entry discharge and exit discharge in the analyzed stretch between the hydrometric stations Sítio dos Patos and Iguatu of the Jaguaribe River from 2000 to 2011.

To develop some comprehension of the magnitude of transmission losses, it is essential to understand the factors that affect these losses. Hacker (2005) mentions that among the most important factors affecting channel losses are: size and sequence of floods; geology and soils of the valley and channels; the gradient, depth, size and continuity of channels; riparian vegetation; depth to the water table; soil-moisture content; gross and gravitational pore space in the soil; man-made structures and alterations; antecedent and current rainfall; and the content and nature of sediment in the stream discharge.

Several authors as Costa et al. (2013) highlight in their studies some of these factors with greater emphasis and comments that transmission losses are strongly related to runoff volume and river velocity. Large floods are normally associated with greater absolute channel losses. The increase in infiltration is due to higher hydraulic head at the surface, unless such floods occur under saturated conditions. The infiltration rate depends strongly on the soil characteristics of the river bed. A gravely, sandy channel and valley may have much higher intake rates per day than finer soils, such as silts and loams or even less for clays. Another interesting point is that the transmission losses occur in any climate but are most common in arid and semi-arid regions.

The value of the calibrated transmission loss parameter $(\mathrm{k})$ was $0.027 \mathrm{~km}^{-1}$, that is, for each $\mathrm{km}, 2.7 \%$ of the discharge is lost. After the Modified Equation of Araújo and Ribeiro (Equation 1) was applied with use of the calibrated parameter, NSE was $82 \%$ and determination coefficient (R2) was 0.89 (Figure 3A) as a result. The calibrated value of the " $k$ " loss is consistent with values found in the literature. For example, Araújo (2002), when analyzing the transmission losses in a $12 \mathrm{~km}$ stretch of the Juazeiro River, in the basin of the Coreaú River in the State of Ceará, used the original equation of Araújo and Ribeiro (1996).

They found an average " $\mathrm{k}$ " loss for the river of $2.3 \% \mathrm{~km}^{-1}$, a value that engendered excellent adjustment in the regression curve, with the discharge values measured at five points along the river. Lima et al. (2007) measured the hydraulic gradient between the river and the aquifer, using wells and piezometers. They found the existence of a maximum discharge in the river-aquifer direction of $9 \mathrm{~m}^{3} \mathrm{~h}^{-1}$ for each $250 \mathrm{~m}$ stretch of the river; that is, $0.01 \mathrm{~m}^{3} \mathrm{~s}^{-1}$ for each $\mathrm{km}$ of the river in the central region of Ceará, in the Vale do Forquilha. 

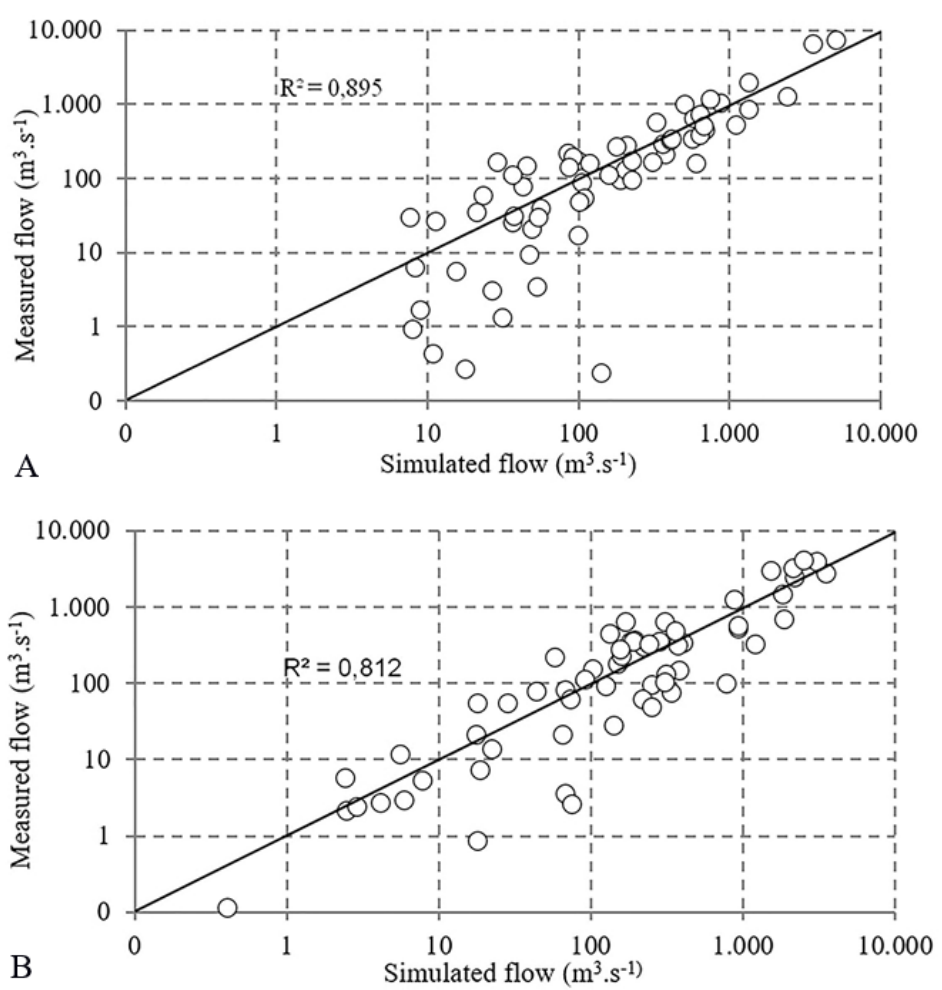

Figure 3. Measured and simulated discharge values at the station of Iguatu, from the events used in the calibration (A) and validation $(\mathrm{B})$ of the transmission loss coefficient $(\mathrm{k})$ for the hydrographic basin of Orós Reservoir.

In the validation of the simulated discharges of the events for the end of the section, there is a variation of 0.4 to $3507 \mathrm{~m}^{3} \mathrm{~s}^{-1}$ compared with 0 to $4112 \mathrm{~m}^{3} \mathrm{~s}^{-1}$ as measured in the hydrometric station of Iguatu (Figure 3B). Therefore, the model again demonstrated a good simulation capacity of the final discharge of a section after yielding an NSE of $81 \%$ and R2 of 0.81 . Based on the good results of NSE for both calibration and validation, the proposed transmission loss equation and its loss coefficient " $\mathrm{k}$ " are classified as efficient in order to simulate the hydrological processes that involve them, according to Moriasi et al. (2007).

The major difficulties found in the parameterization of the transmission loss coefficient in this study were the uncertainties inherent with the hydrometric data (reading errors and data not shown); with pluviometric data (low representativeness of the average value, because of the low number of pluviometric stations -131 for $25000 \mathrm{~km}^{2}$ ); with the identification of events (error in the separation of surface runoff); and with simplifications of the model. According to Costa et al. (2013), the scarcity of hydrological data, especially streamflow discharge and groundwater level series, restricts understanding of transmission loss processes that are associated with the lack of information on spatial river dynamics, and generates uncertainty regarding transmission losses' analysis in large rivers.

One clear example of data uncertainty is the flaw that occurred in the hydrometric station of Iguatu in 2004, in which, after measuring a series of large discharges, records stopped for 8 days (from 09/02 to 16/02), even with an average daily precipitation of $7.8 \mathrm{~mm}$ during that period. In 17/02, the station recorded $1619 \mathrm{~m}^{3} \mathrm{~s}^{-1}$, and again stopped registering for 106 days, although there was in that period a total precipitation of $418.3 \mathrm{~mm}$ in the basin and the stations Sítio Patos, Sítios Dantas and Cariús registered discharges of 4163, 6323 and $8431 \mathrm{~m}^{3} \mathrm{~s}^{-1}$, respectively.

The runoff coefficient equation - RC (Equation 2) varies as a function of the antecedent precipitation. For this reason, initially, the ratio between the surface runoff and the antecedent 
precipitation of the basin was investigated in order to determine the best variation of the runoff coefficient over time. This analysis showed that the precipitation of 5 antecedent days offered the best correlation (R2) with the discharge recorded at the basin hydrometric station, when compared with the antecedent precipitation of 1,2 and 10 days (Figure 4). The antecedent precipitation of 5 days is consistent with the value recommended by the method of the Soil Conservation Service - SCS to parameterize the "curve number" (CN). Many authors, e.g., Silveira et al. (2010), also recommend the use of the antecedent precipitation of 5 days to estimate surface runoff in hydrographic basins.

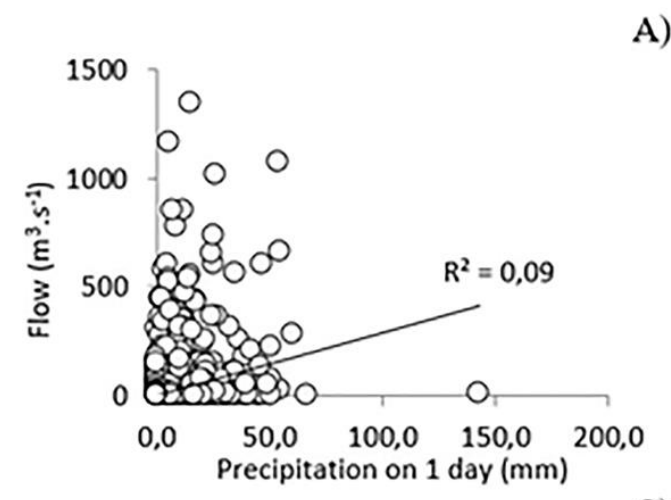

A)
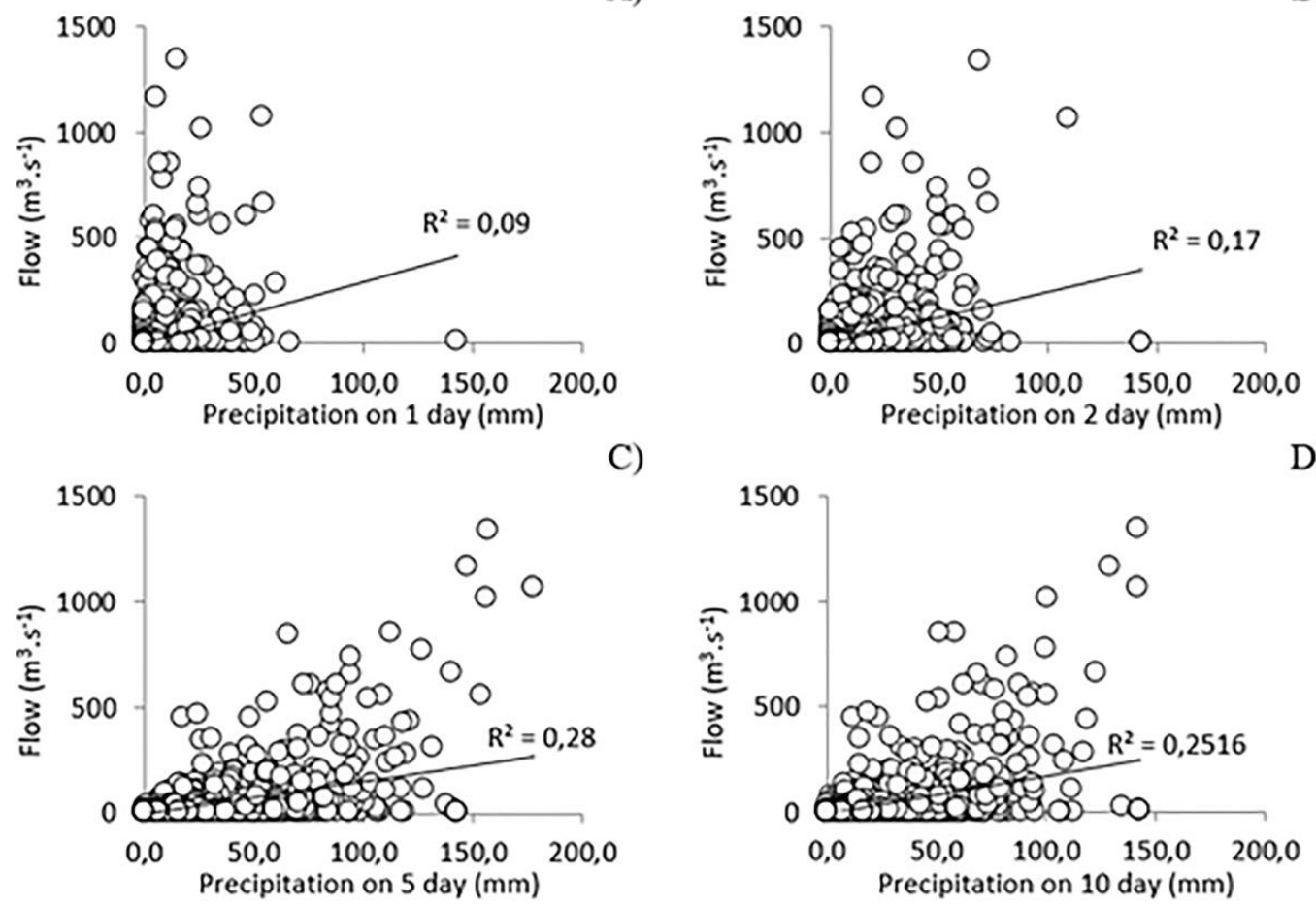

Figure 4. Illustration of the ratio between the antecedent precipitation of one day and the accumulated precipitations of two, five and ten days, and the discharge of the Jaguaribe River recorded in the hydrometric station of Iguatu for the period of 2000 to 2011 . A) Precipitation on 1 antecedent day; B) Precipitation on 2 antecedent days; C) Precipitation on 5 antecedent days; and D) Precipitation on 10 antecedent days.

In the calibration of the RC equation with single values of parameters $\mathrm{K}_{\mathrm{amp}}$ (amplification factor) and $\mathrm{K}_{\mathrm{red}}$ (reduction factor) for the whole Orós Basin (C1), the values achieved were 0.006 and 0.29 , respectively (Table 1 ). However, in the calibration of the same parameters $\mathrm{K}_{\mathrm{amp}}$

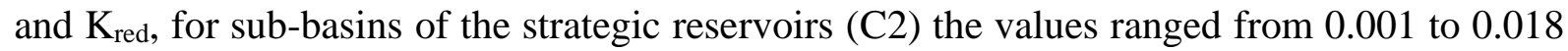
and from 0.10 to 0.96 , respectively. This wide difference in the values of Kamp and Kred obtained when comparing the sub-basins, as well as when compared the sub-basins with the whole basin, evidences the importance of the spatial distribution of the parameters, reflecting in a greater accuracy in the determination of the surface flow.

The results found in this study differed widely from the values reported by Peter et al. (2014), which estimated the parameters Kamp and Kred at 0.60 and 0.92, respectively, also for the whole Orós Basin. This big difference in the values of parameters $K_{a m p}$ and $K_{\text {red }}$ can be attributed to the change in the analysis of antecedent precipitation $\left(\mathrm{P}_{\mathrm{t}-\Delta \mathrm{t}}\right)$. The authors op. cit. used the precipitation of only 1 antecedent day, while the present study used the precipitation of 5 antecedent days (accumulated over 5 days). 
Table 1. Values of amplitude (Kamp) and reduction (Kred) parameters of the temporal variation and/or spatial of the runoff coefficient $(\mathrm{RC})$ : $\mathrm{C} 1$ found for the whole basin using data from the hydrometric Station Sítio Patos installed in the Jaguaribe River and C2 determined for the "sub-basins" of the 18 strategic reservoirs in the basin of the Orós reservoir, evidencing the variation of the runoff coefficient within the basin.

\begin{tabular}{ccccc}
\hline Calibration & Base point of the calibration & Kamp & Kred & RCaverage \\
\hline C1 & Station Sítio Patos - Rio Jaguaribe & 0.006 & 0.29 & 0.03 \\
C2 & Arneiroz II reservoir & 0.015 & 0.32 & 0.05 \\
C2 & Benguê reservoir & 0.004 & 0.70 & 0.02 \\
C2 & Canoas reservoir & 0.002 & 0.91 & 0.04 \\
C2 & Do Coronel reservoir & 0.004 & 0.10 & 0.03 \\
C2 & Faé reservoir & 0.002 & 0.70 & 0.02 \\
C2 & Favelas reservoir & 0.018 & 0.80 & 0.06 \\
C2 & Forquilha II reservoir & 0.010 & 0.12 & 0.02 \\
C2 & Muquém reservoir & 0.016 & 0.11 & 0.07 \\
C2 & Orós reservoir & 0.005 & 0.80 & 0.05 \\
C2 & Parambu reservoir & 0.005 & 0.31 & 0.03 \\
C2 & Pau Preto reservoir & 0.004 & 0.79 & 0.04 \\
C2 & Poço da Pedra reservoir & 0.001 & 0.91 & 0.02 \\
C2 & Quincoé reservoir & 0.003 & 0.30 & 0.02 \\
C2 & Rivaldo Carvalho reservoir & 0.003 & 0.90 & 0.04 \\
C2 & Trici reservoir & 0.012 & 0.12 & 0.03 \\
C2 & Trussu reservoir & 0.018 & 0.91 & 0.12 \\
C2 & Valério reservoir & 0.001 & 0.96 & 0.03 \\
C2 & Várzea do Boi reservoir & 0.018 & 0.40 & 0.07 \\
\hline
\end{tabular}

The analysis of the calibrations showed that the values of $\mathrm{K}_{\mathrm{amp}}$ and $\mathrm{K}_{\text {red }}$ in the calibration for the whole basin are at the same order of magnitude when compared with the average values found in the calibration for the sub-basins $\left(\mathrm{K}_{\mathrm{amp}}=0.008 . \mathrm{K}_{\mathrm{red}}=0.56\right.$ and $\left.\mathrm{RC}=0.04\right)$. However, the results of the calibration for the sub-basins demonstrated a high variability of RC inside the Orós basin. This high variability is attributed to the combination of factors that interfere in different ways in the process of surface runoff, such as pluviometric precipitation, topography, vegetation, depth of the water table, evaporation, use and physical properties of the soil. Santos et al. (2010) emphasized the difficulty in individually identifying the importance of these factors previously mentioned in the mesoscale, because of its multiple influences on surface runoff.

By comparing the efficiency values (NSE) found with RC which vary according to parameters $\mathrm{K}_{\mathrm{amp}}$ and $\mathrm{K}_{\mathrm{red}}$ (calibrated for the sub-basins) with the values found by using $\mathrm{RC}$ fixed in time and space (Figure 5), it can be seen that the use of fixed RC reduced the efficiency of simulating the discharges of most of the analyzed sub-basins. Still, the simulations with fixed $\mathrm{RC}$ have evidenced that the Orós Basin has regions with different hydrological responses.

Peter et al. (2014), performing simulations with the original ResNetM model also for the Orós basin, concluded that the lack of overflow (bleeding) of many reservoirs is an indicator of the need to include spatialization of the runoff coefficients (RC) in the model. We can relate this necessity to the fact that the basin shows different types of soil and vegetation coverage, thus having a direct influence on the runoff of the basin. Thus, it is again confirmed that spatial $\mathrm{RC}$ has to be considered inside the hydrographic basins.

\section{CONCLUSIONS}

Based on the analysis carried out in this research, it can be concluded that the methodology proposed to estimate the losses of water in transit and surface runoff in a semi-arid Brazilian 
basin demonstrated a high efficiency in the simulation of the hydrological processes, being recommended for hydrographic studies.

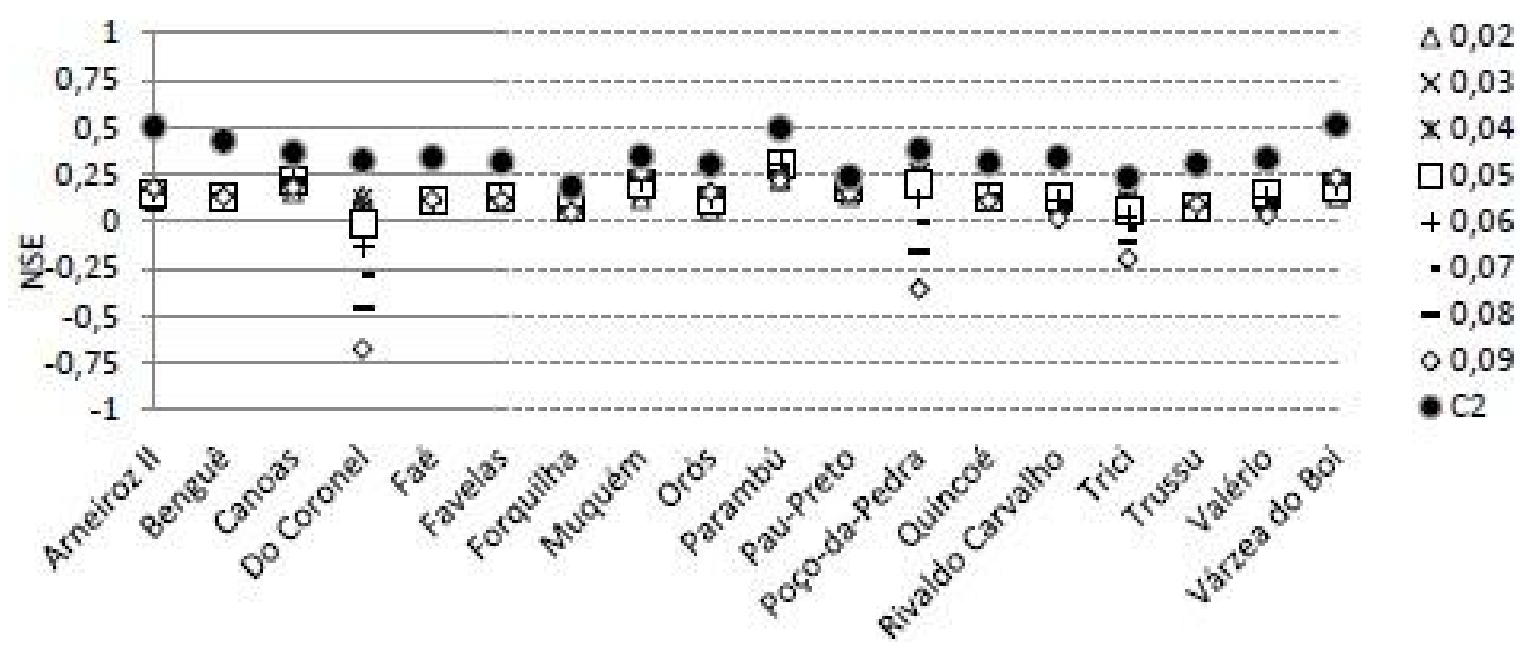

Figure 5. Efficiency values (NSE) found in discharge simulations in sub-basins of hydrographic basin of the Orós Reservoir, taking into account the runoff coefficient found with parameters $K_{a m p}$ and $\mathrm{K}_{\mathrm{red}}$ calibrated for the sub-basins of the strategic reservoirs $(\mathrm{C} 2)$ and the runoff coefficients found in the literature (0.02 to 0.09 ).

Considering the previous 5-day precipitation in determining the runoff coefficient, a significant improvement in the basin runoff estimates was obtained when compared to the simulations considering precipitation of 1,2 and 10 days of anticipation, or even compared with flow simulations using flow coefficients obtained in the literature.

The hydrographic basin of Orós Reservoir presented high variability of the surface runoff coefficient, justifying the need for a greater spatiality of this coefficient in heterogeneous environments.

\section{REFERENCES}

ARAÚJO, J. C. Avaliação de perdas de água em trânsito em rios do Semi-árido. Relatório Técnico. Fortaleza: FUNCEME, 2002.

ARAÚJO, J. C.; RIBEIRO, A. L. Evaluation of water loss in rivers in the Semi-Arid. In: SEMINAR ON WATER RESOURCES IN THE NORTHEAST, 3, 1996, Salvador. Anais[...] Salvador: ABRH, 1996. 12 p.

AYALEW, T. B.; KRAJEWSKI, W. F.; MANTILLA, R.; WRIGHT, D. B. Effect of Spatially Distributed Small Dams on Flood Frequency: Insights from the Soap Creek Watershed.

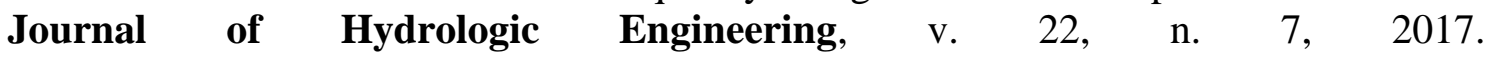
https://doi.org/10.1061/(ASCE)HE.1943-5584.0001513

BRACKEN, L. J.; CROKE, J. The concept of hydrological connectivity and its contribution to understanding runoff-dominated geomorphic systems. Hydrological Processes, v. 1763, p. 1749- 1763, 2007. https://doi.org/10.1002/hyp.6313

COSTA, A. C.; FOERSTER, S.; ARAÚJO, J. A.; BRONSTERT, A. Analysis of channel transmission losses in a dryland river reach in north-eastern Brazil using streamflow series. groundwater level series and multi-temporal satellite data. Hydrological Processes, v.27, n.7, p. 1046-1060, 2013. https://doi.org/10.1002/hyp.9243 
COSTA, A. C.; BRONSTERT, A.; ARAÚJO, J. C. A channel transmission losses model for different dryland rivers. Hydrology Earth System Sciences, v. 16, p. 1111-135, 2012. https://doi.org/10.5194/hess-16-1111-2012

GOOSEFF, M. N.; WLOSTOWSKI, A.; MCKNIGHT, D. M.; JAROS, C. Hydrologic connectivity and implications for ecosystem processes - Lessons from naked watersheds. $\begin{array}{llllll}\text { Geomorphology, } & \text { v. } & 277, & \text { p. } & 63-71,\end{array}$ https://doi.org/10.1016/j.geomorph.2016.04.024

HACKER, F. Model for Water Availability in Semi-Arid Environments (WASA) Estimation of transmission losses by infiltration at rivers in the semi-arid Federal State of Ceará (Brazil). Germany: Institut für Geoökologie/Universität Potsdam, 2005. $41 \mathrm{p}$.

KLEIN, C.; KLEIN, V. A. Influência do manejo do solo na infiltração de água. Revista Monografias Ambientais, v. 13, n. 5, p. 3915-3925, 2014. https://doi.org/10.1016/j.geomorph.2016.04.024

LIMA, C. H. R.; FRISCHKORN, H.; BURTE, J. Avaliação da Interação Rio-Aquífero a Partir de Dados Experimentais e de um Modelo Analítico. Revista Brasileira de Recursos Hídricos, v. 12, n. 1, p. 217-230, 2007. https://doi.org/10.21168/rbrh.v12n1.p217-230

MAMEDE, G. L.; GÜNTNER, A.; MEDEIROS, P. H. A.; ARAÚJO, J. C. Modeling the Effect of Multiple Reservoirs on Water and Sediment Dynamics in a Semiarid Catchment in Brazil. Journal of Hydrologic Engineering, v. 23, n. 12, 2018. https://doi.org/10.1061/(ASCE)HE.1943-5584.0001701

MEDEIROS, P. H. A.; GÜNTNER, A.; FRANCKE, T.; MAMEDE, G.; ARAÚJO, J. C. Modelling spatio-temporal patterns of sediment yield and connectivity at a semi-arid catchment with WASA-SED model. Hydrological Sciences Journal, v. 55, n. 4, p. 636648, 2010. https://doi.org/10.1080/02626661003780409

MORIASI, D. N.; ARNOLD, J. G.; LIEW, M. W. V.; BINGNER, R. L.; HARMEL, R. D.; VEITH, T. L. Model evaluation guidelines for systematic quantification of accuracy in watershed simulations. American Society of Agricultural and Biological Engineers, v. 50, n. 3, p. 885-900, 2007. https://doi.org/10.13031/2013.23153

MVANDABA, V.; HUGHES, D.; KAPANGAZIWIRI, E.; KAHINDA, J. M.; OOSTHUIZEN, $\mathrm{N}$. Modelling of channel transmission loss processes in semi-arid catchments of southern Africa using the Pitman Model. International Association of Hydrological Sciences, v. 378, p. 17-22, 2018. https://doi.org/10.5194/piahs-378-17-2018

PETER, S. J.; ARAÚJO, J. C.; ARAÚJO, N. A. M.; HERRMANN, H. J. Flood avalanches in a semiarid basin with a dense reservoir network. Journal of Hydrology, n. 512, p. 408420, 2014. https://doi.org/10.1016/j.jhydrol.2014.03.001

SANTOS, T. E. M.; SILVA, D. D.; MONTENEGRO, A. A. A. Temporal variability of soil water content under different surface conditions in the semiarid region of the Pernambuco State. Revista Brasileira de Ciência do Solo, v. 34, p. 1733-1741, 2010. https://doi.org/10.1590/S0100-06832010000500025

SILVEIRA, L.; CHARBONNIER, F.; GENTA, J. L. The antecedent soil moisture condition of the curve number procedure. Hydrological Sciences, n. 45, p. 3-12, 2010. https://doi.org/10.1080/02626660009492302 
TOLEDO, C. E.; ARAÚJO, J. C.; ALMEIDA, C. L. The use of remote-sensing techniques to monitor dense reservoir networks in the Brazilian semiarid region. International Journal of Remote Sensing, v. 35, n. 10, p. 3683-3699, 2014. https://doi.org/10.1080/01431161.2014.915593

TOLEDO, C. E.; ALMEIDA, E. M. S.; LOPES NETO, A. V.; SILVA, T. L. G. R.; SANTOS, F. A. R. Water loss in transit in an intermittent river in brazilian semi-arid. Revista Agro@mbiente On-line, v. 12, n. 3, p. 177-190, 2018. http://dx.doi.org/10.18227/19828470ragro.v12i3.5090 